\title{
Establishing a Relationship between Coal Quality and the Enrichment of Radionuclides in Coal Combustion Residues
}

\author{
Uwais Al Qarni Ahmed ${ }^{1,2 *}$, Adriaan Joubert ${ }^{1}$ \\ ${ }^{1}$ National Nuclear Regulator, Eco-Park Estate, Centurion, South Africa \\ ${ }^{2}$ CIMERA, Department of Geology, University of Johannesburg, Kingsway Campus, Auckland Park, Johannesburg, South Africa \\ Email: *uwais78692@yahoo.com
}

How to cite this paper: Ahmed, U.A.Q. and Joubert, A. (2019) Establishing a Relationship between Coal Quality and the Enrichment of Radionuclides in Coal Combustion Residues. World Journal of Nuclear Science and Technology, 9, 113-126. https://doi.org/10.4236/wjnst.2019.93008

Received: May 14, 2019

Accepted: June 21, 2019

Published: June 24, 2019

Copyright $\odot 2019$ by author(s) and Scientific Research Publishing Inc. This work is licensed under the Creative Commons Attribution International License (CC BY 4.0).

http://creativecommons.org/licenses/by/4.0/

\begin{abstract}
Coal-fired power plants (CFPP) provide approximately $40 \%$ of the world's energy demand. Naturally occurring radioactive materials (NORM) contained in coal become enriched in coal combustion residues as a result of the elimination of carbon during combustion. The fly ash and bottom ash produced from CFPP may be significant sources of exposure to naturally occurring radionuclides for the population near the combustion plant or ash dumps. Despite this fact, very few studies have actually addressed the relationship of the NORM enrichment factors and the quality of coal used. This paper aims to relate the quality of coal to the enrichment factors for the radionuclides of interest $\left(\mathrm{K}^{40}, \mathrm{Ra}^{226}, \mathrm{Th}^{232}\right.$ and $\left.\mathrm{Po}^{210}\right)$ in coal combustion residues from three South African CFPP. The data from other CFPP was also taken into account to establish this correlation. The feedstock coal used in these CFPP is typically low quality, with ash content in the range of $25-45$ $\mathrm{wt} \%$. The radionuclides investigated were determined by gamma spectrometry with the exception of $\mathrm{Po}^{210}$, which was determined by alpha spectrometry. The enrichment factors for the radionuclides of $\mathrm{K}^{40}, \mathrm{Ra}^{226}, \mathrm{Th}^{232}$ and $\mathrm{Po}^{210}$ in the fly ash and bottom ash (except $\mathrm{Po}^{210}$ ) was found to be directly proportional to the quality of coal. That is when the ash percentage increased (coal quality decreased) the enrichment factor decreased. The $\mathrm{Po}^{210}$ radionuclide in the bottom ash had an enrichment factor less than one. The relationship between coal quality and enrichment factors for the radionuclides of $\mathrm{K}^{40}, \mathrm{Ra}^{226}, \mathrm{Th}^{232}$ and $\mathrm{Po}^{210}$ in both the fly ash and bottom ash (except $\mathrm{Po}^{210}$ in the bottom ash) was demonstrated by the following mathematical equation:
\end{abstract}

Enrichment Factor $=\frac{1}{\operatorname{Ash}(\%) \text { in feed coal }}$. This equation may be used as a good indication in obtaining an estimate in determining the enrichment of 
the mentioned radionuclides in coal combustion products such as fly ash and bottom ash.

\section{Keywords}

Radionuclides, Coal, Enrichment Factor, Coal Quality

\section{Introduction}

Coal-fired power plants (CFPP) provide approximately $40 \%$ of the world's energy demand [1]. In developing countries, such as South Africa, coal has a significant role in power generation and contributes to approximately $77 \%$ of the country's energy [2]. During coal combustion, the elements in minerals and organic fractions of coal are liberated and distributed into combustion products i.e. fly ash, bottom ash and flue gas [3]. The increase in thermal generation capacity and subsequently a deterioration of the quality of coal used has resulted in increased generation of fly ash and bottom ash of varying properties. Naturally occurring radioactive materials (NORM) are among the inorganic constituents that are present in coal. These radioactive materials are enriched in coal combustion products such as fly ash and bottom ash following the combustion of coal [4]. The installation of ash collectors like cyclones, electrostatic separators and bag filters significantly reduces the emission of radionuclides to the atmosphere [5]. In contrast, the treatment and disposal of power plant ash continues to be problematic, particularly in South Africa where the coal has an inherent high ash content (low quality), typically between $25 \%-50 \%$, and thus a significant amount of ash is generated.

The interest in measuring NORM concentrations in coal and resulting combustion residues (such as fly ash and bottom ash) is due to the awareness of health hazards and environmental pollution [6]. The fly ash and bottom ash produced from CFPP are significant sources of exposure for the population near the plant to naturally occurring radionuclides [7] [8]. The naturally occurring radionuclides, particularly $\mathrm{K}^{40}, \mathrm{Ra}^{226}, \mathrm{Th}^{232}$ and $\mathrm{Po}^{210}$ released by these plants pose a potential health hazard [9]. Due to its short half-life and the highly energetic cell-disrupting alpha particles $(5.3 \mathrm{MeV})$ emitted during its decay process, $\mathrm{Po}^{210}$ is considered a major health hazard [10]. Once $\mathrm{Po}^{210}$ from the air is assimilated into flora and fauna, it may be bio-concentrated in the food chain and, thus, poses further threat to human health [11].

The concentration of most radioactive elements in solid combustion wastes, such as fly ash and bottom ash, will be multiple times higher than the concentration in the original coal [12]. The enrichment factors of certain radionuclides can sometimes be a few folds or even several magnitudes, relative to the feed coals [13]. The number of natural radionuclides discharged into the atmosphere via the ash produced from a CFPP depends on the ash content of coal, the temperature of combustion, partitioning between fly ash and bottom ash, and the ef- 
ficiency of control devices [5] [14].

Several studies wherein coal enrichment factors with respect to certain radionuclides in coal and coal combustion products were conducted by other authors [4] [5] [10] [15]. However, none of these studies actually relates the quality of coal to the enrichment of radionuclides (enrichment factors) in the fly ash and bottom ash. This attribute of coal quality is one that every CFPP is aware of in terms of the coal being burnt. Therefore, knowing the relationship between coal quality and enrichment factors may enable us to determine the concentration of radionuclides in the combustion products prior to the combustion of coal. This may prevent scenarios such as those in China whereby it was found that some coal ash was too radioactive for reuse in building materials [16]. For this very reason, radioactivity in coal and coal combustion residues' uses are being limited [17].

It is hypothesized that the relationship between the concentration of radionuclides in coal and the combustion products i.e. fly ash and bottom ash, is closely related to the quality of coal. Hence, the objectives of this study are to evaluate the ash percentage content (hence quality) of 3 different coals fed to 3 different CFPP and evaluate the enrichment factors in the fly ash and bottom ash (in comparison to other studies as well). As a result, thereof, a mathematical correlation between coal quality and the enrichment factor of radionuclides in coal (in terms of an equation) is to be established, since it does not exist in present-day literature.

\section{Materials and Methods}

\subsection{Sample Collection}

The feed coal to 3 different CFPP from 3 different coalfields in South Africa was used in this study. The coal mines (Figure 1) are in close proximity to the CFPP. Monthly composite samples were sampled on alternate days over a period of 3 months. The three-month period of sampling assured that the samples were representative of the feed coal to each CFPP.

The proximate and ultimate analysis for the feed coal provided for these samples by the power supplier indicated that, over the three months, the feed to the plant was consistent. On the same days as the feed coal was sampled, the fly ash (from the hoppers) and bottom ash (from the boiler) from the 3 CFPP were also sampled. This ensured that the fly ash and bottom ash were indeed products of the sampled feed coal. The gross samples were then air-dried, milled (coal and bottom ash) and carefully split in accordance with ISO recommendations in order to obtain a representative sample of particle size $<250$ um prior to chemical analyses.

\subsection{Sample Processing and Analyses}

The feed coal samples were supplied together with the proximate data by the power utility and were analysed in accordance with ISO 18283:2006 [19] and 


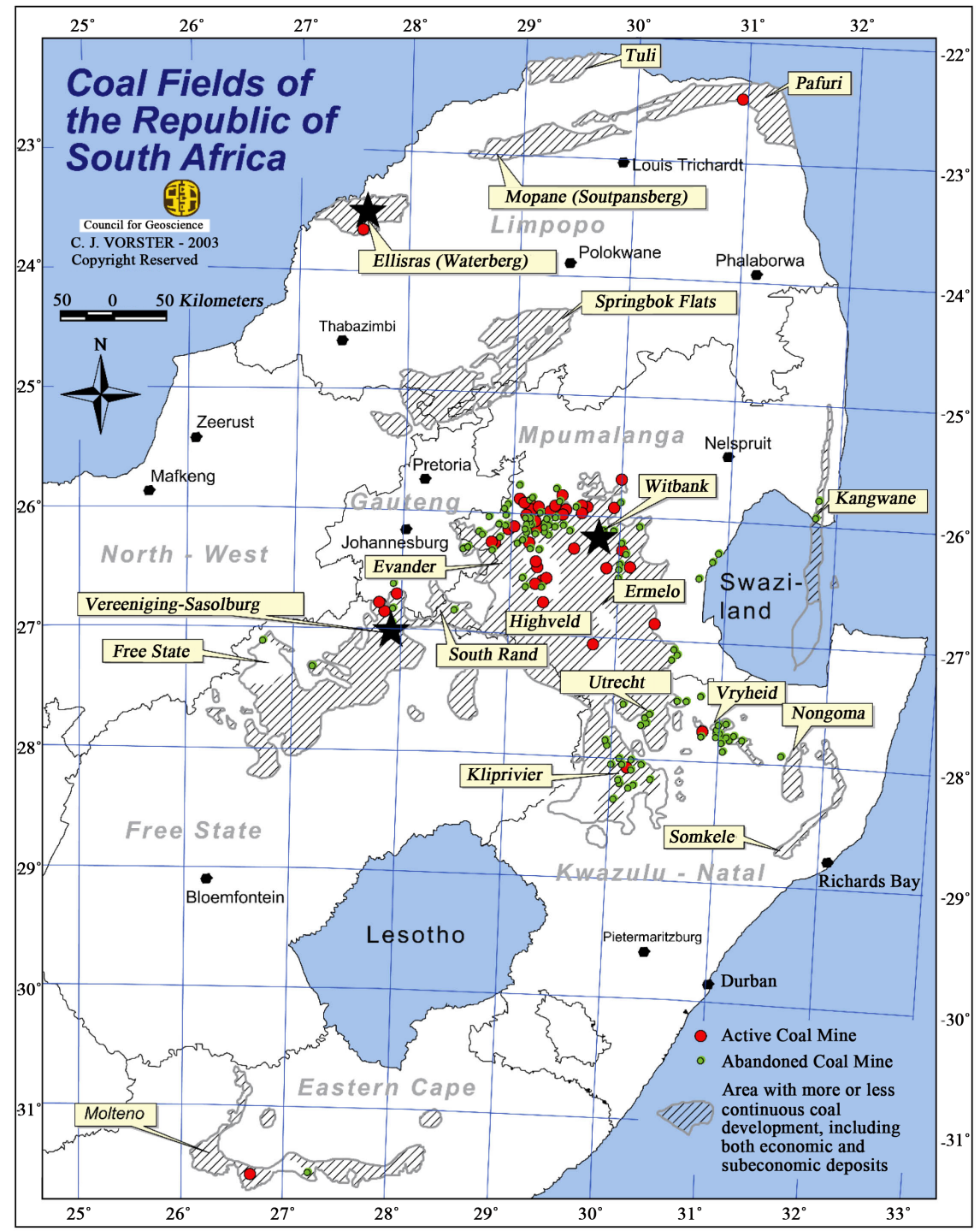

Figure 1. Coalfields of the Republic of South Africa [18]. The location of the CFPP are indicated.

ISO 13909:2001 [20]. Therefore, the quality of coal was concluded based on the ash yield and classified accordingly as indicated in Table 1 .

In order to determine the radionuclides of interest $\left(\mathrm{K}^{40}, \mathrm{Ra}^{226}, \mathrm{Th}^{232}\right.$ and $\left.\mathrm{Po}^{210}\right)$ in the samples, two routes were followed. For $\mathrm{K}^{40}, \mathrm{Ra}^{226}$ and $\mathrm{Th}^{232}$, gamma spectrometry was conducted; for $\mathrm{Po}^{210}$ alpha spectrometry was conducted.

For gamma spectrometry, the coal and ash samples were dried for 24 hours in an air-circulation oven at $110^{\circ} \mathrm{C}$. Samples were further pulverized to obtain a fine powder and sieved for homogeneity. Thereafter, $100 \mathrm{~g}$ of each sample was placed in plastic containers of $6.5 \mathrm{~cm}$ diameter $\times 7.5 \mathrm{~cm}$ height, and sealed to make them airtight. The samples were left for a period of 1 month in a designated laboratory cupboard to ascertain the establishment of secular equilibrium between $\mathrm{Ra}^{226}$ and $\mathrm{Th}^{228}$ with their progeny and to prevent Rn loss. The specific radionuclides of the samples-i.e. $\mathrm{K}^{40}, \mathrm{Ra}^{226}$ and $\mathrm{Th}^{232}$-were determined using a 
Table 1. Ash categorisation of the feed coals.

\begin{tabular}{ccc}
\hline CFPP location & Ash Yield & $\begin{array}{c}\text { Ash Class Category } \\
\text { (According to ISO 11760:2005) [21] }\end{array}$ \\
\hline Witbank & $25.27 \%(\geq 20$ and $<30)$ & Moderately high ash \\
Waterberg & $32.84 \%(\geq 30$ and $<50)$ & High ash \\
Sasolburg & $40.85 \%(\geq 30$ and $<50)$ & High ash \\
\hline
\end{tabular}

high-resolution, p-type coaxial HPGe $\gamma$-ray spectrometer shielded by cylindrical lead. The detector relative efficiency was $28.2 \%$ and energy resolution of 1.67 $\mathrm{keV}$-FWHM at the $1.33 \mathrm{MeV}$ peak of $\mathrm{Co}^{60}$. A cylindrical multi-nuclide source was used for detector energy calibration and efficiency determination [22]. The measured detection efficiencies were fitted by using a polynomial fitting function, as described by Khandaker et al. [23], and the fitted efficiencies were used in activity determination of the samples. The minimum detectable activity (MDA) of the $\gamma$-ray measurement system at $95 \%$ confidence level was calculated according to the procedure by Khandaker et al. [23]. Each sample was counted for $86,400 \mathrm{~s}$, and similarly for background counts, in order to obtain the net activity.

The same method used by Sahu et al. [10] was used to determine the $\mathrm{Po}^{210}$ using alpha spectrometry. Samples (5 $\mathrm{g}$ of each) were first digested with $\mathrm{HNO}_{3}$ and $4 \mathrm{~N} \mathrm{HCl}$ sequentially. The acids were evaporated to near dryness and made up to $80 \mathrm{~mL}$ by adding $1 \mathrm{~N} \mathrm{HCl}$ with ascorbic acid to reduce interfering $\mathrm{Fe}(\mathrm{III})$. Tracer activity $3.0 \mathrm{~Bq} / \mathrm{ml}$ including $\mathrm{Po}^{209}$ was added to the aliquots. Then silver planchets were submerged into the solutions and were kept at a temperature of about $85^{\circ} \mathrm{C}$ for $7 \mathrm{~h}$ with continuous stirring. The planchets thereafter were dried under infra-red lamp and alpha activities were determined in the alpha spectrometer. Samples were counted in an eight-chamber integrated alpha spectrometry system equipped with ion-implanted Si-charged-particle detectors, with an active detector-surface area of $450 \mathrm{~mm}^{2}$, and a source-to-detector distance of approximately $10 \mathrm{~mm}$. Samples and blanks were counted for nominally 250,000 s. Background measurements were made immediately prior to the measurements.

\section{Results and Discussion}

Table 2 presents the quality of coal used in the three CFPP and their coal and resultant coal combustion residues' radionuclide concentration in comparison with other studies [24] [25].

\subsection{Radionuclide Concentrations in Coal, Fly Ash and Bottom Ash}

The quality of coal used in South Africa varies between the CFPP [26], and is generally of low grade. The values obtained here are comparable to those reported by [27] for coals typically supplied to these three CFPP's. The quality of coal used can be classified as moderately high ash to high ash coal according to 
Table 2. Ash categorisation of the feed coals and radionuclide concentrations in coal, fly ash and bottom ash for the three CFPP in comparison with other studies [24] [25].

\begin{tabular}{|c|c|c|c|c|c|c|c|}
\hline \multirow{2}{*}{ Sample } & & \multirow{2}{*}{ Ash } & \multirow{2}{*}{$\mathrm{N}$} & \multicolumn{4}{|c|}{ Activity of radionuclide $(\mathrm{Bq} / \mathrm{kg})$} \\
\hline & & & & $\mathrm{K}^{40}$ & $\mathrm{Ra}^{226}$ & $\mathrm{Th}^{232}$ & $\mathrm{Po}^{210}$ \\
\hline \multirow{3}{*}{ Witbank (Present Study) } & Fuel (Coal) & & 9 & $88 \pm 6$ & $21 \pm 1$ & $22 \pm 4$ & $46 \pm 1$ \\
\hline & Fly ash & $25 \%$ & 9 & $348 \pm 8$ & $80 \pm 3$ & $88 \pm 6$ & $193 \pm 8$ \\
\hline & Bottom ash & & 9 & $334 \pm 8$ & $63 \pm 3$ & $84 \pm 6$ & $41 \pm 7$ \\
\hline \multirow{3}{*}{ Waterberg (Present Study) } & Fuel (Coal) & & 9 & $91 \pm 3$ & $52 \pm 5$ & $21 \pm 1$ & $70 \pm 5$ \\
\hline & Fly ash & $33 \%$ & 9 & $319 \pm 4$ & $166 \pm 8$ & $63 \pm 6$ & $280 \pm 8$ \\
\hline & Bottom ash & & 9 & $302 \pm 5$ & $150 \pm 13$ & $82 \pm 8$ & $3 \pm 1$ \\
\hline \multirow{3}{*}{ Sasolburg (Present Study) } & Fuel (Coal) & & 9 & $110 \pm 4$ & $24 \pm 5$ & $19 \pm 3$ & $83 \pm 3$ \\
\hline & Fly ash & $41 \%$ & 9 & $286 \pm 4$ & $65 \pm 6$ & $45 \pm 6$ & $265 \pm 13$ \\
\hline & Bottom ash & & 9 & $242 \pm 13$ & $51 \pm 6$ & $44 \pm 2$ & $2 \pm 1$ \\
\hline \multirow{3}{*}{ Spain: Teruel UPT [25] } & Fuel (Coal) & & 2 & $66 \pm 15$ & $54 \pm 3$ & $21 \pm 3$ & $65 \pm 11$ \\
\hline & Fly ash & $22 \%$ & 2 & $306 \pm 13$ & $191 \pm 9$ & $74 \pm 3$ & $257 \pm 30$ \\
\hline & Bottom ash & & 2 & $235 \pm 11$ & $149 \pm 6$ & $66 \pm 3$ & $57 \pm 7$ \\
\hline \multirow{3}{*}{ Spain: Litoral UPT [25] } & Fuel (Coal) & & 2 & $70 \pm 16$ & $15 \pm 3$ & $13 \pm 3$ & $33 \pm 4$ \\
\hline & Fly ash & $16 \%$ & 2 & $338 \pm 16$ & $107 \pm 4$ & $87 \pm 4$ & $300 \pm 40$ \\
\hline & Bottom ash & & 2 & $278 \pm 16$ & $81 \pm 4$ & $64 \pm 4$ & $7 \pm 1$ \\
\hline \multirow{3}{*}{ Spain: Compostilla II [24] } & Fuel (Coal) & & 2 & $334 \pm 13$ & $34 \pm 3$ & $33 \pm 3$ & $118 \pm 40$ \\
\hline & Fly ash & $37 \%$ & 2 & $1109 \pm 49$ & $94 \pm 4$ & $93 \pm 4$ & $416 \pm 57$ \\
\hline & Bottom ash & & 2 & $1077 \pm 48$ & $86 \pm 2$ & $89 \pm 3$ & $24 \pm 12$ \\
\hline \multirow{3}{*}{ Spain: Teruel [24] } & Fuel (Coal) & & 2 & $77 \pm 32$ & $56 \pm 5$ & $21 \pm 2$ & $65 \pm 11$ \\
\hline & Fly ash & $28 \%$ & 2 & $310 \pm 14$ & $190 \pm 2$ & $74 \pm 2$ & $257 \pm 30$ \\
\hline & Bottom ash & & 2 & $238 \pm 13$ & $149 \pm 5$ & $66 \pm 3$ & $57 \pm 7$ \\
\hline \multirow{3}{*}{ Spain: Litoral [24] } & Fuel (Coal) & & 4 & $62 \pm 30$ & $18 \pm 4$ & $20 \pm 6$ & $47 \pm 20$ \\
\hline & Fly ash & $15 \%$ & 4 & $250 \pm 144$ & $158 \pm 48$ & $154 \pm 53$ & $505 \pm 321$ \\
\hline & Bottom ash & & 4 & $224 \pm 105$ & $144 \pm 55$ & $138 \pm 61$ & $9 \pm 4$ \\
\hline
\end{tabular}

ISO [21]. For all of the CFPP samples, the radionuclide concentrations in the coals are in close proximity with the world averages $\left(\mathrm{K}^{40}, 4-785 \mathrm{~Bq} / \mathrm{kg} ; \mathrm{Ra}^{226}, 1\right.$ $206 \mathrm{~Bq} / \mathrm{kg} ; \mathrm{Th}^{232}, 1-170 \mathrm{~Bq} / \mathrm{kg}$; and $\mathrm{Po}^{210}, 3-52 \mathrm{~Bq} / \mathrm{kg}$ ) as indicated by the IAEA [28].

Although the radionuclide concentration in coal may be in line with the world averages, the concentrations of these are expected to be multiple times higher in the coal combustion products (fly ash and bottom ash) than the concentration in the original coal [12] and are commonly termed as the enrichment factor or 
enrichment ratio. The enrichment ratio is the concentration of the nuclide in ash to its concentration in the feed coal [10]. The results of radionuclides in the fly ash and bottom ash from Table 2 certainly indicate the enrichment of radionuclides from the coal to the fly ash and bottom ash. The activity levels of $\mathrm{K}^{40}, \mathrm{Ra}^{226}$, and $\mathrm{Th}^{232}$ are very similar to each other in both the fly ash and bottom ash samples for all three plants in the current study. These correlate with the results from the two other studies tabulated. However, there are significant differences between the $\mathrm{Po}^{210}$ concentrations in the fly ash and bottom ash. This is because most of the $\mathrm{Po}^{210}$ is vaporized during combustion in the boiler [25]. This phenomenon will be expanded on in the next section. The $\mathrm{K}^{40}, \mathrm{Ra}^{226}, \mathrm{Th}^{232}$ and $\mathrm{Po}^{210}$ activity concentration levels for the fly ash and bottom ash for this study are in close proximity to the values reported by Mora et al. [25] and Baeza et al. [24], which are presented in Table 2. The average activity levels given in the UNSCEAR report [29] for fly ash are $265 \mathrm{~Bq} / \mathrm{kg}$ for $\mathrm{K}^{40}, 240 \mathrm{~Bq} / \mathrm{kg}$ for $\mathrm{Ra}^{226}, 70$ $\mathrm{Bq} / \mathrm{kg}$ for $\mathrm{Th}^{232}$ and $1700 \mathrm{~Bq} / \mathrm{kg}$ for $\mathrm{Po}^{210}$.

\subsection{Enrichment Factors and Coal Quality}

The enrichment factor for each radionuclide for the fly ash and bottom ash for each of the CFPP is reported in Table 3 together with the results from other studies [24] [25].

Table 3. Coal quality and their respective enrichment factors for the three CFPP in comparison with other studies [24] [25].

\begin{tabular}{|c|c|c|c|c|c|c|}
\hline \multirow{2}{*}{ Sample } & & \multirow{2}{*}{ Ash } & \multicolumn{4}{|c|}{ Enrichment Factor } \\
\hline & & & $\mathrm{K}^{40}$ & $\mathrm{Ra}^{226}$ & $\mathrm{Th}^{232}$ & $\mathrm{Po}^{210}$ \\
\hline \multirow{2}{*}{ Witbank } & Fly ash & \multirow{2}{*}{$25 \%$} & $3.9 \pm 0.8$ & $3.8 \pm 0.3$ & $4 \pm 0.7$ & $4.1 \pm 0.1$ \\
\hline & Bottom ash & & $3.8 \pm 0.8$ & $3 \pm 0.3$ & $3.8 \pm 0.7$ & $0.9 \pm 0.1$ \\
\hline \multirow{2}{*}{ Waterberg } & Fly ash & \multirow[t]{2}{*}{$33 \%$} & $3.5 \pm 0.8$ & $3.1 \pm 0.6$ & $3 \pm 0.2$ & $4 \pm 0.6$ \\
\hline & Bottom ash & & $3.3 \pm 0.6$ & $2.9 \pm 0.4$ & $3.9 \pm 0.1$ & 0 \\
\hline \multirow{2}{*}{ Sasolburg } & Fly ash & \multirow{2}{*}{$41 \%$} & $2.6 \pm 1$ & $2.7 \pm 0.8$ & $2.4 \pm 0.5$ & $3.2 \pm 0.2$ \\
\hline & Bottom ash & & $2.2 \pm 0.3$ & $2.1 \pm 0.8$ & $2.3 \pm 0.7$ & 0.0 \\
\hline \multirow{2}{*}{ Spain: Teruel UPT [25] } & Fly ash & \multirow{2}{*}{$22 \%$} & $4.6 \pm 0.9$ & $3.5 \pm 0.3$ & $3.5 \pm 0.2$ & $4 \pm 0.3$ \\
\hline & Bottom ash & & $3.6 \pm 0.7$ & $2.8 \pm 0.7$ & $3.1 \pm 0.1$ & $0.9 \pm 0.6$ \\
\hline \multirow{2}{*}{ Spain: Litoral UPT[25] } & Fly ash & \multirow{2}{*}{$16 \%$} & $4.8 \pm 0.1$ & $7.1 \pm 0.8$ & $6.7 \pm 0.1$ & $9 \pm 0.1$ \\
\hline & Bottom ash & & $4 \pm 0.1$ & $5.4 \pm 0.8$ & $4.9 \pm 0.1$ & $0.2 \pm 0.3$ \\
\hline \multirow{2}{*}{ Spain: Compostilla II [24] } & Fly ash & \multirow{2}{*}{$37 \%$} & $3.3 \pm 0.2$ & $2.8 \pm 0.3$ & $2.8 \pm 0.3$ & $4 \pm 1$ \\
\hline & Bottom ash & & $3.2 \pm 0.2$ & $2.5 \pm 0.2$ & $2.7 \pm 0.3$ & $0.2 \pm 0.1$ \\
\hline \multirow{2}{*}{ Spain: Teruel [24] } & Fly ash & \multirow{2}{*}{$28 \%$} & $4 \pm 2$ & $3.4 \pm 0.3$ & $3.5 \pm 0.3$ & $4 \pm 1$ \\
\hline & Bottom ash & & $3 \pm 1$ & $2.7 \pm 0.3$ & $3.1 \pm 0.3$ & $1 \pm 0.2$ \\
\hline \multirow{2}{*}{ Spain: Litoral [24] } & Fly ash & \multirow{2}{*}{$15 \%$} & $4 \pm 3$ & $9 \pm 3$ & $8 \pm 3$ & $11 \pm 8$ \\
\hline & Bottom ash & & $4 \pm 2$ & $8 \pm 3$ & $7 \pm 4$ & $0.2 \pm 0.1$ \\
\hline
\end{tabular}




\subsubsection{Fly Ash and Coal Quality}

In most cases, the enrichment factors in this study were approximately $2-4$ times higher in the ashes than in the feed coal. This is commonly observed in other studies [10] [30]. The enrichment factor for all the samples were higher for the fly ash compared to the bottom ash. This is because the radionuclides concentrate on the smaller fly ash particles that have a larger surface area-to-volume ratio and the hot flu gases cool down on their way to stack [31]. An exception to the enrichment of $2-4$ times is that of $\mathrm{Po}^{210}$ in the bottom ash.

For the present study, the highest enrichment factor was for $\mathrm{Po}^{210}$ in the Witbank fly ash. The enrichment of $\mathrm{Po}^{210}$ in the fly ash is $2-4$ times higher. The lowest enrichment factor in the fly ash was $\mathrm{Th}^{232}$ that was for the Sasolburg coal. In bottom ash the highest enrichment factor of 3.90 was observed for $\mathrm{Th}^{232}$ in the Waterberg coal and the lowest enrichment factor was 2.13 for $\mathrm{Ra}^{226}$ in the Sasolburg coal. In all cases, the fly ash had higher enrichment factors for all the radionuclides when compared to bottom ash, which is consistent with previous studies conducted [10] [32] [33].

The enrichment factor for each radionuclide determined in the fly ash (Table 3 ) was plotted against the ash content of the coal in order to establish a correlation (Figures 2-6).

It is apparent (from Figures 2-5) that the enrichment factor for $\mathrm{K}^{40}, \mathrm{Ra}^{226}$, $\mathrm{Th}^{232}$ and $\mathrm{Po}^{210}$ in the fly ash samples decreased as the \%ash increased. This indicates that the enrichment factors for these specific radionuclides in these coals are directly proportional to coal quality as expressed by ash. A strong correlation (indicated by the $\mathrm{R}^{2}$ values which are approximately $>0.7$ in Figures $2-5$ ) was obtained for the concentration the $\mathrm{K}^{40}, \mathrm{Ra}^{226}$ and $\mathrm{Th}^{232}$ radionuclides in relation to the quality of coal, whilst the correlation for $\mathrm{Po}^{210}$ was moderately strong i.e. $\mathrm{R}^{2}=0.62634$.

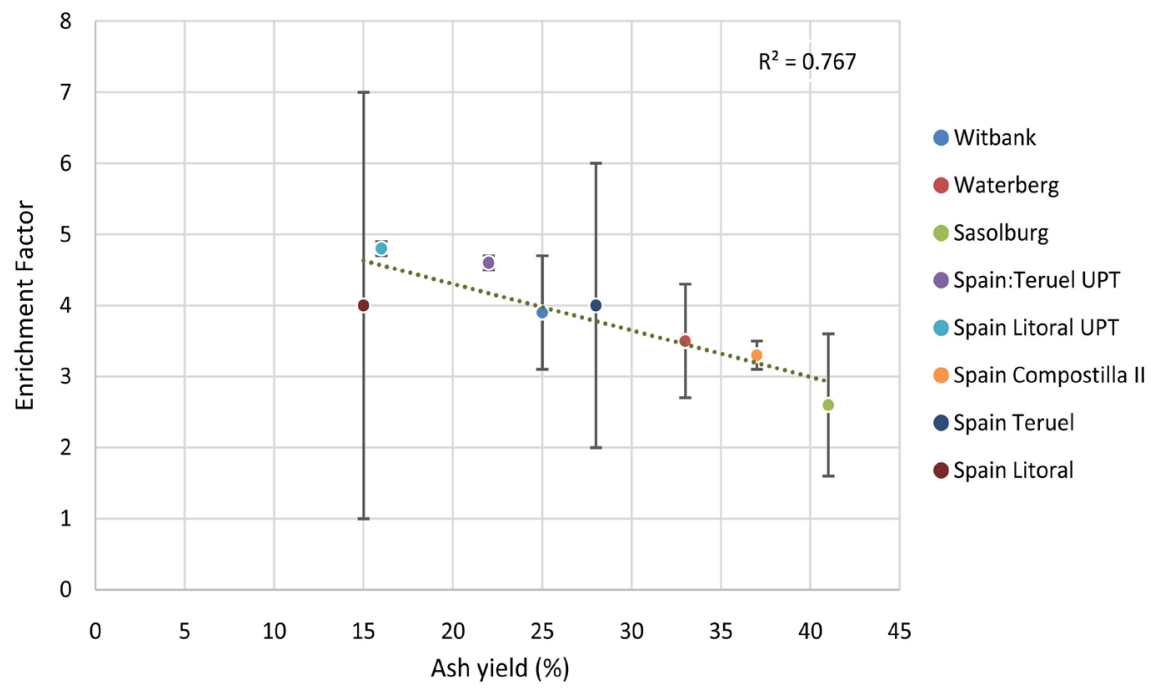

Figure 2. Correlation for $\mathrm{K}^{40}$ in the fly ash for the enrichment factor and the ash content in various coal samples. 


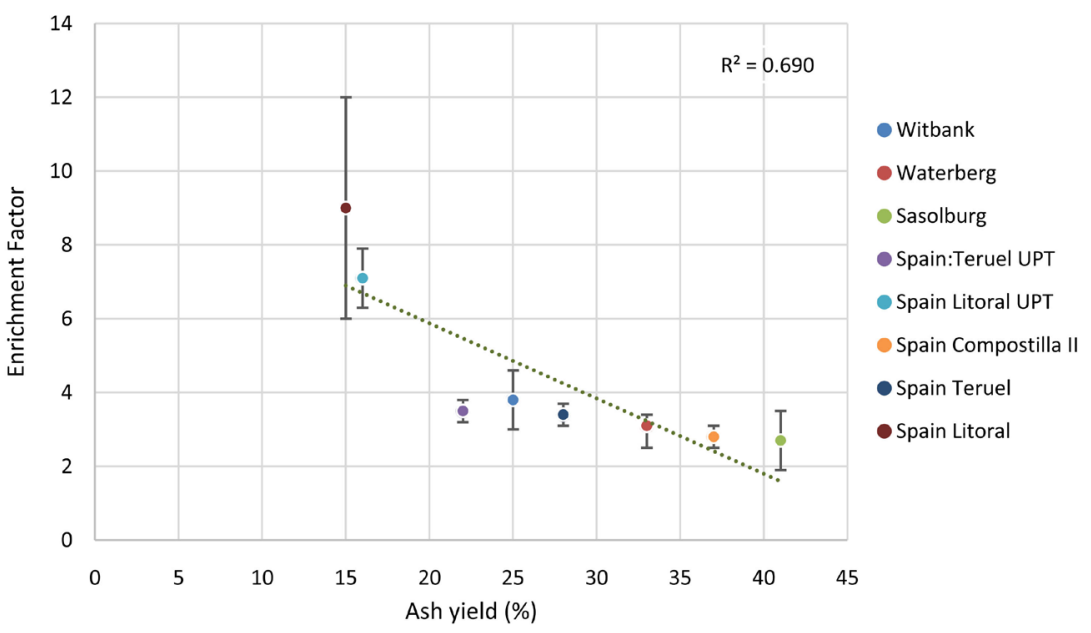

Figure 3. Correlation for $\mathrm{Ra}^{226}$ in the fly ash for the enrichment factor and the ash content in various coal samples.

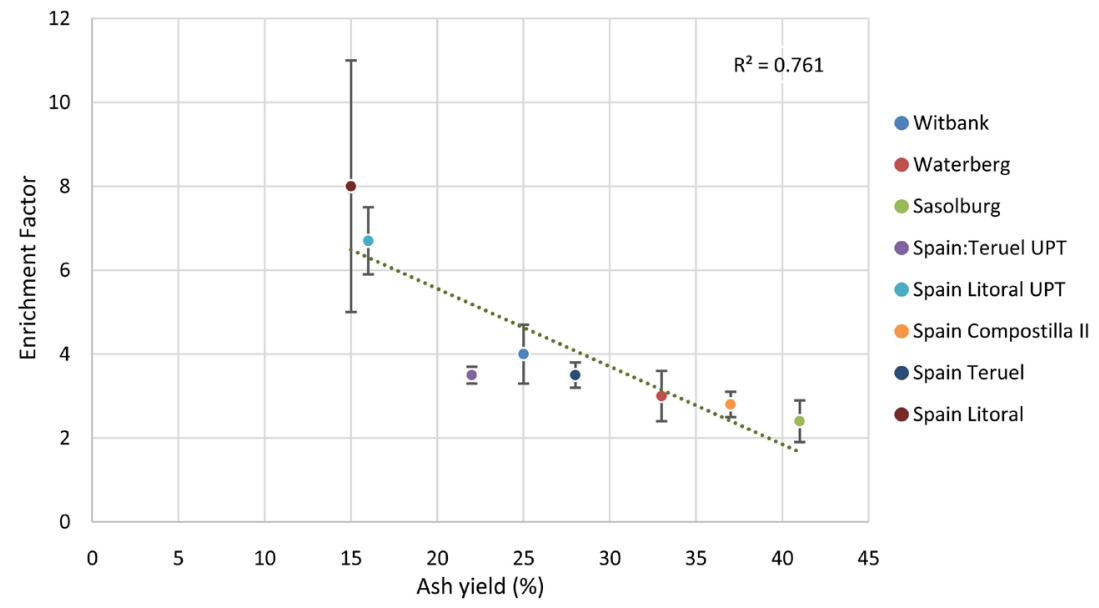

Figure 4. Correlation for $\mathrm{Th}^{232}$ in the fly ash for the enrichment factor and the ash content in various coal samples.

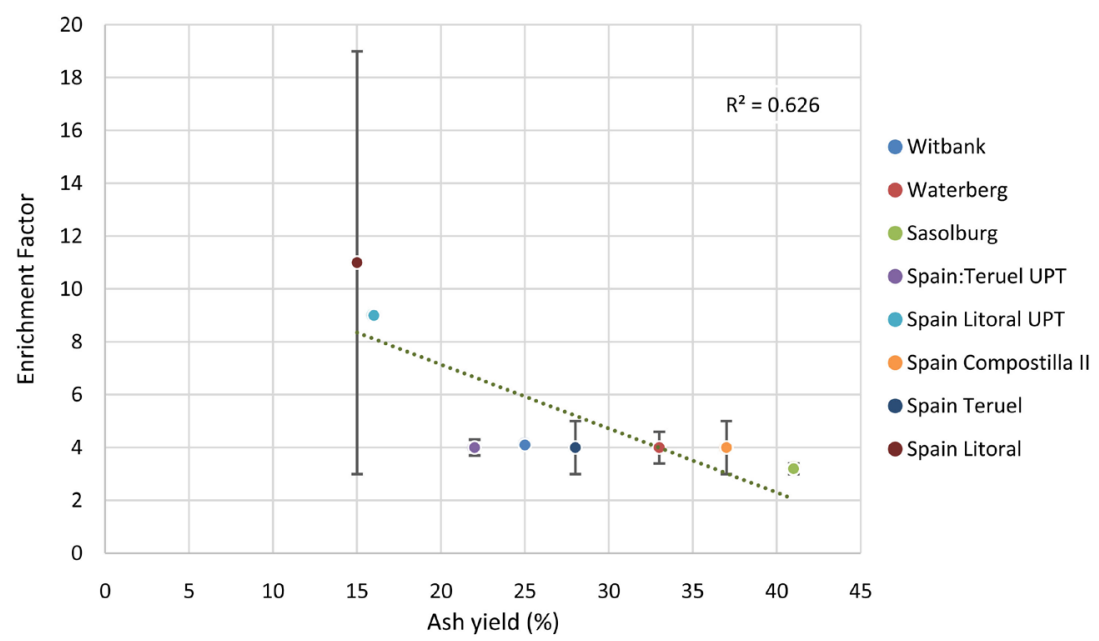

Figure 5. Correlation for $\mathrm{Po}^{210}$ in the fly ash for the enrichment factor and the ash content in various coal samples. 


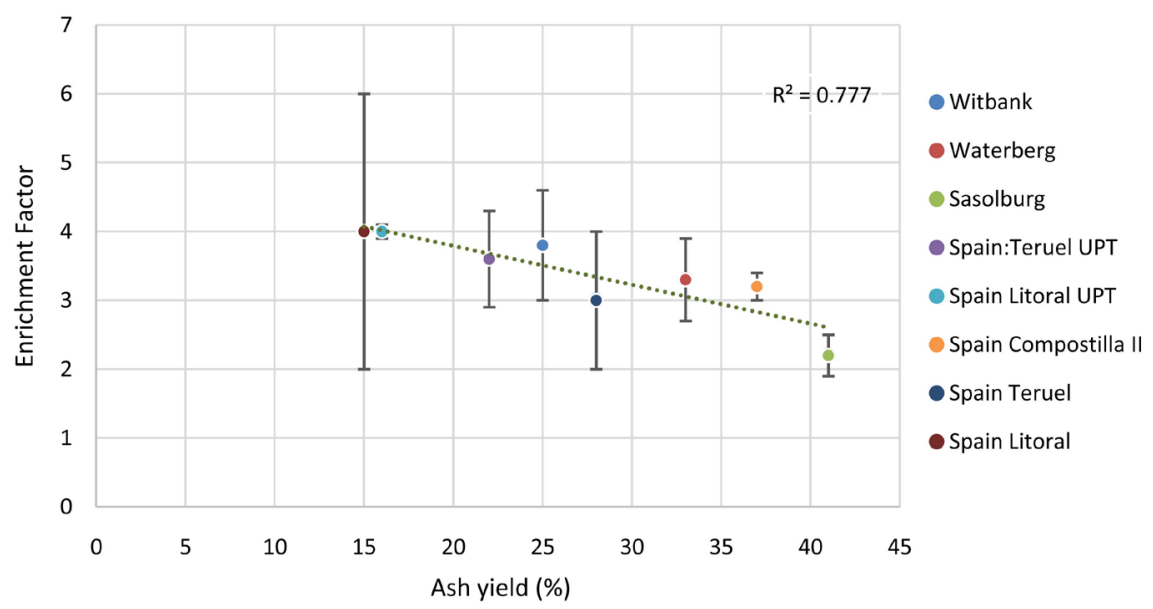

Figure 6. Correlation for $\mathrm{K}^{40}$ in the bottom ash for the enrichment factor and the ash content in various coal samples.

\subsubsection{Bottom Ash and Coal Quality}

The enrichment factors for each radionuclide in the bottom ash (Table 3) was correlated with the ash content of coal as shown in Figures 6-9.

In terms of the bottom ash, the enrichment factors also seems to be directly proportional to the ash content. However, a strong correlation is only present in $\mathrm{K}^{40}\left(\mathrm{R}^{2}=0.7777\right)$ whereas the $\mathrm{R}^{226}$ and $\mathrm{Th}^{232}$ present only a moderately strong correlation (as opposed to strong correlations in the fly ash). It is interesting to note that this relationship is applicable to all the radionuclides $\left(\mathrm{K}^{40}, \mathrm{Ra}^{226}\right.$ and $\mathrm{Th}^{232}$ ) except $\mathrm{Po}^{210}$. In fact, $\mathrm{Po}^{210}$ exhibits no correlation $\left(\mathrm{R}^{2}=0.0854\right)$ and the enrichment factors for $\mathrm{Po}^{210}$ in the bottom ash for all the CFPP is less than unity, and therefore indicates that $\mathrm{Po}^{210}$ is depleted from the feed coal to bottom ash. This is because, as mentioned, the Po compounds are associated with sulphide minerals and are mostly volatilized during the combustion process; they later condense onto smaller fly ash particles which have larger specific areas and thus their levels get elevated in the fine fly ash fraction [10].

The results indicate that the enrichment factors for the radionuclides $\mathrm{K}^{40}$, $\mathrm{Ra}^{226}, \mathrm{Th}^{232}$ and $\mathrm{Po}^{210}$ in the fly ash and bottom ash are in close proximity with each other (except $\mathrm{Po}^{210}$ in the bottom ash). The results indicate that the enrichment factor is approximately 4,3 and 2.4 when the ash content is $25 \%, 33 \%$ and $41 \%$ respectively. Mora et al. [25] observed that the enrichment factors in fly ash in relation to coal were 6.1 and 4.6 when the ash content in coals was $16 \%$ and $22 \%$ respectively. Lauer et al. [4] conclude that a $7-10$ fold enrichment is expected from the elimination of carbon during combustion from coals containing $10 \%-15 \%$ ash content, which is typical for low ash U.S coals. This leads to the following equation to determine the enrichment factor for radionuclides in coal prior to the combustion of the coal by simply considering the $\%$ ash content:

$$
\text { Enrichment Factor }=\frac{1}{\text { Ash }(\%) \text { in feed coal }}
$$

Although not precise, the equation may be used as an excellent estimate (or 


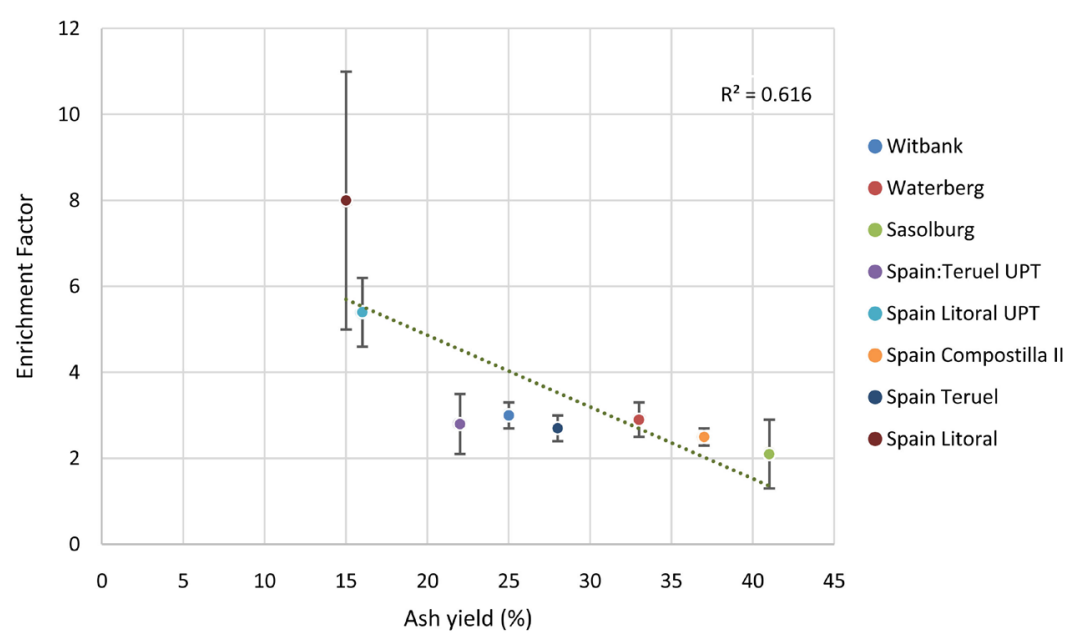

Figure 7. Correlation for $\mathrm{Ra}^{226}$ in the bottom ash for the enrichment factor and the ash content in various coal samples.

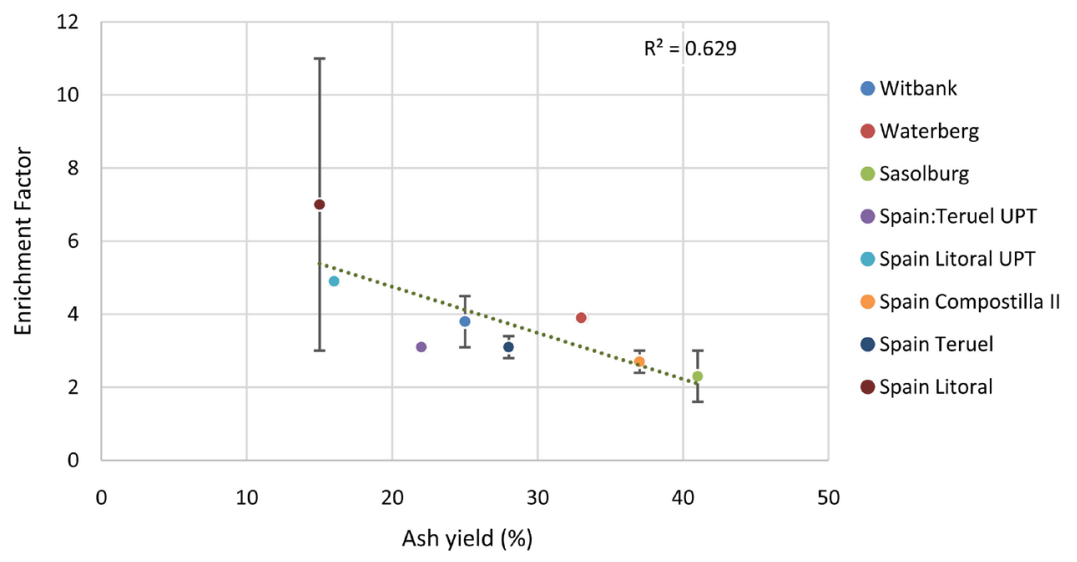

Figure 8. Correlation for $\mathrm{Th}^{232}$ in the bottom ash for the enrichment factor and the ash content in various coal samples.

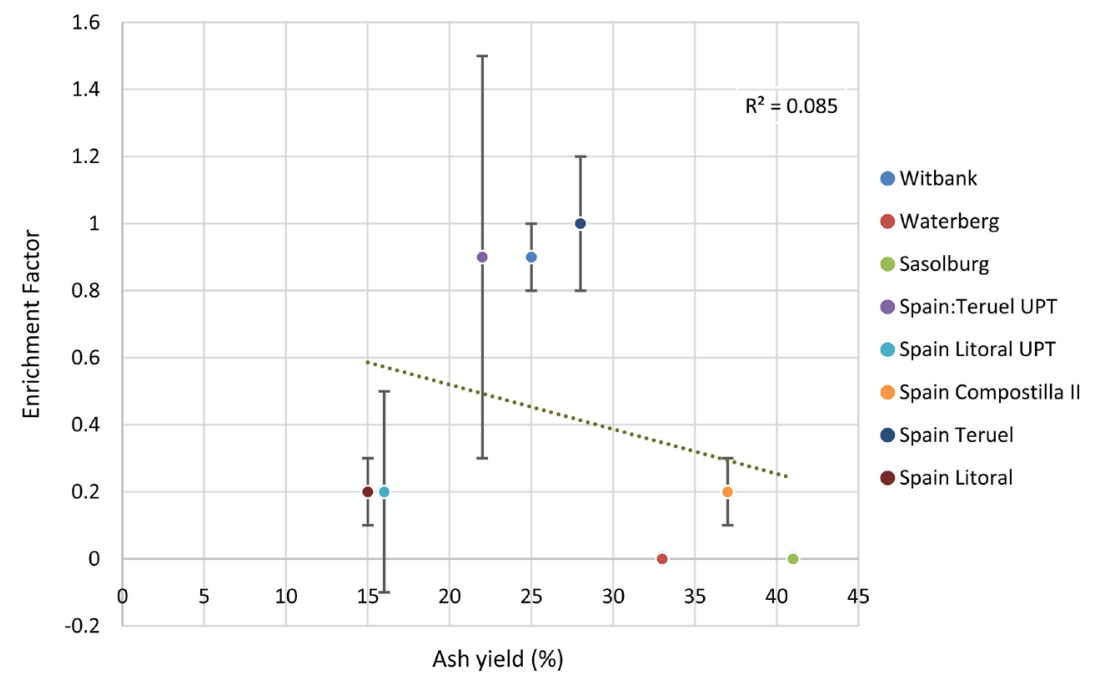

Figure 9. Correlation for $\mathrm{Po}^{210}$ in the bottom ash for the enrichment factor and the ash content in various coal samples. 
rule of thumb) in determining the enrichment of radionuclides such as $\mathrm{K}^{40}, \mathrm{Ra}^{226}$ and $\mathrm{Th}^{232}$ in coal combustion products.

\section{Conclusions}

When coal is burnt, the radionuclide concentration increases multiple times from the coal to the fly ash and bottom ash. The relationship between this enrichment of radionuclides (in the fly ash and bottom ash) and the quality of coal was investigated using samples from 3 different CFPP in South Africa in comparison with other studies.

It was found that the coals used in these CFPP were typically low quality coal, ranging between $25 \%$ - $45 \%$ ash content. The enrichment factor for the radionuclides $\mathrm{K}^{40}, \mathrm{Ra}^{226}, \mathrm{Th}^{232}$ and $\mathrm{Po}^{210}$ were 2 - 4 times higher in the ashes than in the feed coal (with the exception of $\mathrm{Po}^{210}$ in the bottom ash). The enrichment factor for the radionuclides of $\mathrm{K}^{40}, \mathrm{Ra}^{226}, \mathrm{Th}^{232}$ and $\mathrm{Po}^{210}$ and in the fly ash was found to be directly proportional to the ash content; i.e. when the ash $\%$ increased (coal quality decreases) the enrichment factor decreased. The relationship for the enrichment factor for the radionuclides $\mathrm{K}^{40}, \mathrm{Ra}^{226}$ and $\mathrm{Th}^{232}$ in the bottom ash also showed the same directly proportional relationship to coal quality i.e. as the coal quality decreased the enrichment factor also decreased. However, this was not obeyed for the $\mathrm{Po}^{210}$ radionuclide, which had an enrichment factor less than unity in the bottom ash samples.

The relationship between coal quality and enrichment factors for the radionuclides of $\mathrm{K}^{40}, \mathrm{Ra}^{226}, \mathrm{Th}^{232}$, and $\mathrm{Po}^{210}$ in both the fly ash and bottom ash (except $\mathrm{Po}^{210}$ in the bottom ash) was demonstrated by using the following mathematical equation:

$$
\text { Enrichment Factor }=\frac{1}{\text { Ash }(\%) \text { in feed coal }}
$$

This equation may be used a good indication in obtaining a ball park figure in determining the enrichment of radionuclides such as $\mathrm{K}^{40}, \mathrm{Ra}^{226}$ and $\mathrm{Th}^{232}$ in coal combustion products such as fly ash and bottom ash.

\section{Conflicts of Interest}

The authors declare no conflicts of interest regarding the publication of this paper.

\section{References}

[1] International Energy Outlook (2011). https://www.eia.gov/outlooks/ieo/

[2] Energy.gov.za. (2019) Energy Sources: Coal. Department: Energy, Republic of South Africa. http://www.energy.gov.za/files/coal_frame.html

[3] Tang, Q., Liu, G., Yan, Z. and Sun, R. (2012) Distribution and Fate of Environmentally Sensitive Elements (Arsenic, Mercury, Stibium and Selenium) in Coal-Fired Power Plants at Huainan, Anhui, China. Fuel, 95, 334-339.

https://doi.org/10.1016/j.fuel.2011.12.052 
[4] Lauer, N.E., Hower, J.C., Hsu-Kim, H., Taggart, R.K. and Vengosh, A. (2015) Naturally Occurring Radioactive Materials in Coals and Coal Combustion Residuals in the United States. Environmental Science \& Technology, 49, 11227-11233. https://doi.org/10.1021/acs.est.5b01978

[5] Flues, M., Camargo, I., Silva, P. and Mazzilli, B. (2006) Radioactivity of Coal and Ashes from Figueira Coal Power Plant in Brazil. Journal of Radioanalytical and $\mathrm{Nu}$ clear Chemistry, 270, 597-602. https://doi.org/10.1007/s10967-006-0467-0

[6] Tadmor, J. (1986) Radioactivity from Coal-Fired Power Plants: A Review. Journal of Environmental Radioactivity, 4, 177-204. https://doi.org/10.1016/0265-931X(86)90010-X

[7] Zeevaert, T., Sweeck, L. and Vanmarcke, H. (2006) The Radiological Impact from Airborne Routine Discharges of a Modern Coal-Fired Power Plant. Journal of Environmental Radioactivity, 85, 1-22. https://doi.org/10.1016/j.jenvrad.2005.04.015

[8] Sahu, S.K., Bhangare, R.C., Ajmal, P.Y., Sharma, S., Pandit, G.G. and Puranik, V.D. (2009) Characterization and Quantification of Persistent Organic Pollutants in Fly Ash from Coal Fueled Thermal Power Stations in India. Microchemical Journal, 92, 92-96. https://doi.org/10.1016/j.microc.2009.02.003

[9] Mishra, U.C. (2004) Environmental Impact of Coal Industry and Thermal Power Plants in India. Journal of Environmental Radioactivity, 72, 35-40. https://doi.org/10.1016/S0265-931X(03)00183-8

[10] Sahu, S.K., Tiwari, M., Bhangare, R.C. and Pandit, G.G. (2014) Enrichment and Particle Size Dependence of Polonium and Other Naturally Occurring Radionuclides in Coal Ash. Journal of Environmental Radioactivity, 138, 421-426. https://doi.org/10.1016/j.jenvrad.2014.04.010

[11] Daish, S.R., Dale, A.A., Dale, C.J., May, R. and Rowe, J.E. (2005) The Temporal Variations of ${ }^{7} \mathrm{Be},{ }^{210} \mathrm{~Pb}$ and ${ }^{210} \mathrm{Po}$ in Air in England. Journal of Environmental Radioactivity, 84, 457-467. https://doi.org/10.1016/j.jenvrad.2005.05.003

[12] Ozden, B., Guler, E., Vaasma, T., Horvath, M., Kiisk, M. and Kovacs, T. (2018) Enrichment of Naturally Occurring Radionuclides and Trace Elements in Yatagan and Yenikoy Coal-Fired Thermal Power Plants, Turkey. Journal of Environmental Radioactivity, 188, 100-107. https://doi.org/10.1016/j.jenvrad.2017.09.016

[13] Bhattacharyya, S., Donahoe, R.J. and Patel, D. (2009) Experimental Study of Chemical Treatment of Coal Fly Ash to Reduce the Mobility of Priority Trace Elements. Fuel, 88, 1173-1184. https://doi.org/10.1016/j.fuel.2007.11.006

[14] Amin, Y.M., Uddin Khandaker, M., Shyen, A.K.S., Mahat, R.H., Nor, R.M. and Bradley, D.A. (2013) Radionuclide Emissions from a Coal-Fired Power Plant. Applied Radiation and Isotopes, 80, 109-116.

https://doi.org/10.1016/j.apradiso.2013.06.014

[15] Sahoo, S.K., Parami, V.K., Quirit, L.L., Yonehara, H., Ishikawa, T. and Tokonami, S. (2011) Determination of Uranium Concentrations and Its Activity Ratios in Coal and Fly Ash from Philippine Coal-Fired Thermal Power Plants Using ICP-MS and TIMS. Radiochimica Acta, 1, 257-261.

[16] Lauer, N., Vengosh, A. and Dai, S. (2017) Naturally Occurring Radioactive Materials in Uranium-Rich Coals and Associated Coal Combustion Residues from China. Environmental Science \& Technology, 51, 13487-13493. https://doi.org/10.1021/acs.est.7b03473

[17] Benedette Cuffari, M. (2019) How Radioactive Coal Is Limiting Its Use. https://www.azomining.com/Article.aspx?ArticleID=1377 
[18] Council for Geoscience (2018) Council for Geoscience. http://www.geoscience.org.za/index.php/publication/downloadable-material

[19] ISO (2006) Hard Coke and Coal Manual Sampling. South African Bureau of Standards.

[20] ISO (2001) Hard Coal and Coke-Mechanical Sampling Part 6: Coke-Preparation of Test Samples. South African Bureau of Standards.

[21] ISO (2005) Classification of Coals. South African Bureau of Standards.

[22] Asaduzzaman, K., Khandaker, M.U., Amin, Y.M., Bradley, D.A., Mahat, R.H., Nor, R.M. (2014) Soil-to-Root Vegetable Transfer Factors for ${ }^{226} \mathrm{Ra},{ }^{232} \mathrm{Th},{ }^{40} \mathrm{~K}$, and ${ }^{88} \mathrm{Y}$ in Malaysia. Journal of Environmental Radioactivity, 135, 120-127. https://doi.org/10.1016/j.jenvrad.2014.04.009

[23] Khandaker, M., Wahib, N., Amin, Y. and Bradley, D. (2013) Committed Effective Dose from Naturally Occuring Radionuclides in Shellfish. Radiation Physics and Chemistry, 88, 1-6. https://doi.org/10.1016/j.radphyschem.2013.02.034

[24] Baeza, A., Corbacho, J.A., Guillén, J., Salas, A., Mora, J.C., Robles, B. and Cancio, D. (2012) Enhancement of Natural Radionuclides in the Surroundings of the Four Largest Coal-Fired Power Plants in Spain. Journal of Environmental Monitoring, 14, 1064-1072. https://doi.org/10.1039/c2em10991c

[25] Mora, J.C., Baeza, A., Robles, B., Corbacho, J.A. and Cancio, D. (2009) Behaviour of Natural Radionuclides in Coal Combustion. Radioprotion, 44, 577-580.

[26] Energy.gov.za. (2019). http://www.energy.gov.za/files/media/explained/South-African-Coal-Sector-Report. pdf

[27] Pinheiro, H.J. (1999) A Techno-Economic and Historical Review of the South African Coal Industry in the 19th and 20th Centuries, and Analyses of Coal Product Samples of South African Collieries 1998-1999. Bulletin 113, SABS, 97 p.

[28] IAEA (2003) Extent of Environmental Contamination by Naturally Occurring Radioactive Material (NORM) and Technological Options for Mitigation. International Atomic Energy Agency, Vienna.

[29] UNSCEAR (1993) Sources and Effects of Ionizing Radiation. United Nations Scientific Committee on the Effects of Atomic Radiation, United Nations, New York.

[30] Xinwei, L., Xiaodan, J. and Fengling, W. (2006) Natural Radioactivity of Coal and Its Byproducts in the Baoji Coal-Fired Power Plant, China. Current Science, 91, 1508-1511.

[31] Papastefanou, C., Manolopoulou, M. and Charalambous, S. (1984) Exposure from the Radioactivity in Building Materials. Health Physics, 47, 775-783.

[32] Bem, H., Wieczorkowski, P. and Budzanowski, M. (2002) Evaluation of Technologically Enhanced Natural Radiation Near the Coal-Fired Power Plants in the Lodz Region of Poland. Journal of Environmental Radioactivity, 61, 191-201. https://doi.org/10.1016/S0265-931X(01)00126-6

[33] Gu, H., Zheng, R., Zhang, W., Wu, Z. and Kong, L. (1996) Natural Radioactive Level in Coal and Ash and Building Material Products from Coal-Fired Power Plants in Beijing. Radiation Protection, 16, 309-316. 